\begin{tabular}{|l|l|l||}
\hline \multicolumn{2}{|c|}{ PublisherInfo } \\
\hline \hline PublisherName & $:$ & BioMed Central \\
\hline \hline PublisherLocation & $:$ & London \\
\hline \hline PublisherImprintName & $:$ & BioMed Central \\
\hline \hline
\end{tabular}

\title{
Xena: small cloned piglet
}

\begin{tabular}{|l|l|l||}
\hline \multicolumn{2}{|c|}{ ArticleInfo } \\
\hline \hline ArticleID & $:$ & 3747 \\
\hline \hline ArticleDOI & $:$ & $10.1186 /$ gb-spotlight-20000818-02 \\
\hline \hline ArticleCitationID & $:$ & spotlight-20000818-02 \\
\hline \hline ArticleSequenceNumber & $:$ & 184 \\
\hline \hline ArticleCategory & $:$ & Research news \\
\hline \hline ArticleFirstPage & $:$ & 1 \\
\hline \hline ArticleLastPage & $:$ & 2 \\
\hline \hline & & RegistrationDate : 2000-08-18 \\
ArticleHistory & $:$ & OnlineDate $\quad$ 2000-08-18 \\
\hline \hline ArticleCopyright & $:$ & BioMed Central Ltd2000 \\
\hline \hline ArticleGrants & $:$ & \\
\hline \hline ArticleContext & $:$ & 130591111 \\
\hline \hline
\end{tabular}




\section{William Wells}

Email: wells@biotext.com

On 2 July 2000, a small black piglet was delivered by a white sow. Xena's dark color was a clue that she was not the warrior princess whose name she bears but the product of the first successful pig cloning from fetal cells. As reported in the 18 August Science, this cloning adds to reports of cloned sheep, cattle, and goats (Onishi et al., Science 2000, 289:1188-1190). Xena was produced using a technique developed in mice in which a nucleus from a somatic cell is microinjected into an enucleated oocyte. This technique contrasts with the cell-fusion method used to produce Dolly. It took the transfer of 110 embryos to produce one live cloned piglet. But if the process can be made more efficient, Xena's creators hope to use cloning to propagate pigs with good growth characteristics, and to make genetic changes that will allow pig organs to be used in xenotransplants.

\section{References}

1. Xena, Warrior Princess, [http://www.xenafan.com]

2. Science Magazine, [http://www.sciencemag.org/]

3. Sheep cloned by nuclear transfer from a cultured cell line.

4. Eight calves cloned from somatic cells of a single adult.

5. Production of goats by somatic cell nuclear transfer.

6. Full-term development of mice from enucleated oocytes injected with cumulus cell nuclei.

7. Sheep cloned by nuclear transfer from a cultured cell line. 